\title{
Detection of and response to a probable volcanogenic T-wave event swarm on the western Blanco Transform Fault Zone
}

\author{
R. P. Dziak ${ }^{1}$, C. G. Fox ${ }^{2}$, R. W. Embley², J. E. Lupton ${ }^{2}$, G. C. Johnson ${ }^{3}$, \\ W. W. Chadwick ${ }^{1}$, and R. A. Koski ${ }^{4}$
}

\begin{abstract}
The East Blanco Depression (EBD), a pull-apart basin within the western Blanco Transform Fault Zone (BTFZ), was the site of an intense earthquake T-wave swarm that began at $1317 Z$ on January 9,1994 . Although tectonically generated earthquakes occur frequently along the BTFZ, this swarm was unusual in that it was preceded and accompanied by periodic, low-frequency, long-duration acoustic signals, that originated from near the swarm epicenters. These tremor-like signals were very similar in character to acoustic energy produced by a shallow-submarine eruption near Socorro Island, a seamount several hundred km west of Baja, California. The -69 earthquakes and -400 tremor-like events at the EBD occurred sporadically, with two periods of peak activity occurring between January 5-16 and 27-31. The swarm-like character of the earthquakes and the similarity of the tremor activity to the Socorro eruption indicated that the EBD was undergoing an intrusion or eruption episode. On January 27, six CTD/rosette casts were conducted at the site. Water samples from two of the stations yielded anomalous ${ }^{3} \mathrm{He}$ concentrations, with maxima at 2800 m depth over the main basin. In June 1994 two camera tows within the basin yielded evidence of pillow-lava volcanism and hydrothermal deposits, but no conclusive evidence of a recent seafloor eruption. In September 1994, deployments of the U.S. Navy's Advanced Tethered Vehicle resulted in the discovery of an active hydrothermal mound on the flanks of a pillowlava volcano. The hydrothermal mound consists of Fe-rich hydrothermal precipitate and bacterial mats. Temperatures to $60^{\circ} \mathrm{C}$ were measured $30 \mathrm{~cm}$ below the surface. This is the first discovery of active hydrothermal vents along an oceanic fracture zone. Although no conclusive evidence of volcanic activity associated with the T-wave event swarm was found during these response efforts, the EBD has been the site of recent seafloor eruptions.
\end{abstract}

\section{Introduction}

Tertiary (T) waves are seismically generated acoustic waves that propagate over great distances in the oceanic sound channel. On August 29, 1991, the National Oceanic and Atmospheric Administration (NOAA) began continuously recording digital data from the Navy's fixed hydrophone array (SOSUS) systems in the northeast Pacific ocean [Fox et al., 1994]. On June 22, 1993, NOAA installed a prototype system at the U.S. Naval Facility Whidbey Island to allow real-time acoustic monitoring of the northeast Pacific. Earthquake and volcanic tremor Twaves associated with the June/July 1993 magmatic-dike injection along the CoAxial Segment (Juan de Fuca Ridge) have

\footnotetext{
${ }^{1}$ Cooperative Institute for Marine Resources Studies, Oregon State University, Newport, Oregon.

${ }^{2}$ Pacific Marine Environmental Laboratory, NOAA, Hatfield Marine Science Center, Newport, Oregon.

${ }^{3}$ Pacific Marine Environmental Laboratory, NOAA, Seattle, Washington.

${ }^{4}$ United States Geological Survey, Menlo Park, California.

Copyright 1996 by the American Geophysical Union.
}

Paper number 96 GL00240

0094-8534/96/96GL-00240\$05.00 been well documented using this system [Dziak et al., 1995; Fox et al., 1995]. Unprecedented water column and geologic groundtruth information was provided through rapid response efforts to the CoAxial eruption site [Baker et al., 1995; Embley et al., 1995; Lupton et al., 1995]. On January 2, 1994, low-frequency periodic signals were detected from the western Blanco Transform Fault Zone (BTFZ). These tremor-like signals, later interpreted to be of volcanic origin, occurred intensely over the next 4 weeks. On January 9 a large earthquake swarm began within the East Blanco Depression (EBD) (Figure 1). This paper examines the spatio-temporal distribution of $\mathrm{T}$-wave earthquakes and tremor-like signals observed during the episode at the EBD, the findings of three major response efforts that surveyed the water column and seafloor in the region, and the implications for volcanic and hydrothermal processes along oceanic fracture zones.

The BTFZ, located in the Pacific Ocean off the coast of Oregon, is a right-lateral transform fault that links the moderatespreading rate Juan de Fuca and Gorda Ridges (Figure 1). The BTFZ has generated numerous large earthquakes $\left(m_{b} \leq 6.1\right)$ that are tectonic in origin [Dziak et al., 1991]. Utilizing highresolution multibeam sonar bathymetry [Embley and Wilson, 1992] divided the BTFZ into five major right-stepping strikeslip fault segments that are separated by deep extensional basins. These basins were interpreted to be the oceanic analog of pullapart basins along continental divergent wrench-fault systems. The East Blanco Depression, a pull-apart basin in the western third of the BTFZ (Figure 1), exhibits extensional fabric oblique to the trend of the strike-slip fault segments.

Evidence for volcanic activity within pull-apart basins along oceanic-transform faults is not uncommon, especially transforms along the fast-spreading East Pacific Rise. Fresh pillow-lava flows and young constructional volcanic mounds have been found along the Clipperton [Kastens et al., 1986], the Garret [Hekinian et al., 1992], and the Siqueiros [Perfit et al., 1993] transform fault zones. Although the majority of recent-lava flows along these transform faults are located within their pullapart basins, the Siqueiros and Garret exhibit recent flows along their strike-slip fault segments as well. Evidence for recent extrusive volcanism within a continental pull-apart basin is rare, possibly due to the thick crust along continental strike-slip faults. A prime example of a pull-apart basin within a continental wrench fault that exhibits high-heat flow and Quaternary volcanic activity is the Salton Trough along the southern San Andreas-Imperial Fault system [Newmark et al., 1988]. In the Salton Trough, early-Pleistocene diabase sills have intruded to within a few kilometers of the surface, and are thought to be the heat sources driving the hydrothermal system.

\section{T-wave Event Detection}

The East Blanco Depression earthquake swarm began at $1317 Z$ on January 9, 1994, with a total of 61 earthquakes occurring over a 3-day period. The T-waves from this earthquake swarm were detected and located using formed-beams from the U.S. Navy's SOSUS hydrophone arrays within the NE Pacific Ocean (Figures 1 and 2). Formed-beams were used because they improve the signal/noise ratio of the T-wave event records [Fox et al., 1994]. Since none of the events were detected by land-based seismic networks [National Earthquake 


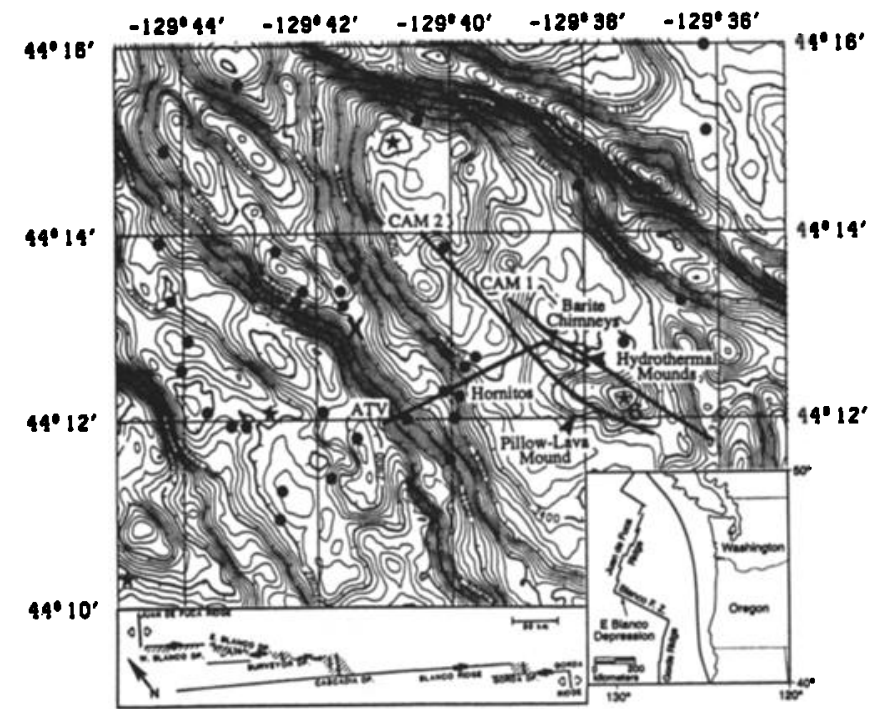

Figure 1. Bathymetric map of the Blanco Transform Fault Zone ( $20-\mathrm{m}$ contours). The circles show the estimated epicenters of the T-wave earthquake swarm. The " $X$ " denotes the event location centroid. Stars are the location of CTD cast sites near the EBD, with cast site "6" (anomalous $\mathrm{He}^{3} / \mathrm{He}^{4}$ profile) labeled. Also shown are the camera-tow and ATV dive tracklines and the locations of the pillow-lava mound, hydrothermal mounds, barite chimneys, and homitos found during the collective response efforts. The bottom-left inset is a structural interpretation map of the Blanco Transform Fault Zone (after Embley and Wilson [1992)]. The pullapart basins (depressions) are shaded, strike-slip fault segments are labeled with opposing arrows. The bottom-right inset is a sketch of northeast Pacific plate boundaries with the locations of the Blanco Transform Fault Zone and East Blanco Depression.

Information Center, 1994], and few were detected by SOSUS omni-directional hydrophones, the swarm earthquakes were all probably low magnitude events $\left(m_{b} \leq 4\right)$. However, seismic activity associated with volcanic systems tends to occur at magnitudes below 4 [Einarsson, 1991]. The earthquakes were located using a non-linear regression algorithm that minimizes error between observed and predicted arrival times [Dziak et al., 1995]. It was difficult to select a consistent peak arrival phase for each earthquake, possibly due to either local bathymetric roughness, the volcanic nature of the events, a deep-crustal source for the earthquakes, or all of these factors. The inconsistent arrival picks resulted in the rather large scatter in event locations (Figure 1). For the purposes of a response effort, the centroid of the event cluster $\left(44^{\circ} 13.0^{\prime} 4.2^{\prime \prime} \mathrm{N}, 129^{\circ} 41.3^{\prime} 5^{\prime \prime} \mathrm{W}\right)$ was taken to be the practical source of the earthquakes.

The earthquake swarm was preceded and accompanied by low-frequency long-duration acoustic signals that originated from near the swarm epicenters (Figure 2). The earthquakes differ significantly in acoustic character from the low frequency signals in that the earthquakes are short-duration, impulsive, and broad-band. The unidentified acoustic events are longer in duration, emergent, low-frequency $(-2-20 \mathrm{~Hz})$, and most importantly have arrival times that are periodic (every $\sim 15-20$ minutes). All periodic events had low source levels ( $\leq 190 \mathrm{~dB}$ ) and were rarely detected on two hydrophone arrays, making precise location impossible. However, since arrival time data from each hydrophone array can be used to estimate a bearing to a signal's source, the detection of the periodic events on two hydrophone arrays made it possible to roughly estimate their location. The bearings from two hydrophone arrays to the periodic events intersected at the East Blanco Depression. The error in bearing locations does not allow for greater location accuracy other than indicating that the periodic events occurred within the EBD.

The periodic tremor-like signals were interpreted as volcanogenic because of their similarity to T-wave arrivals, detected by the SOSUS hydrophone arrays, from an eruption offshore of Socorro Island (Figure 2). Socorro Island is located several hundred kilometers west of the Baja California coast $\left(18^{\circ} 45^{\prime} \mathrm{N}\right.$, $110^{\circ} 57^{\prime} \mathrm{W}$ ). Eruption activity began on January 16,1993 , when Mexican Naval authorities based on Socorro Island began feeling continuous seismic activity [Bulletin of the Global Volcanism Network (BGVN), 1993]. Then on January 19, strong T-wave signals from the area were detected throughout the a) E.B.D. Tremor

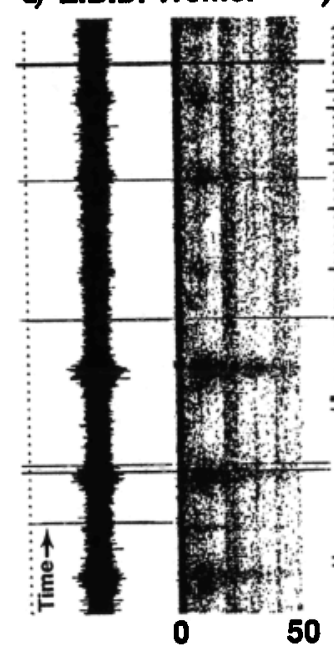

b) E.B.D. Earthquakes

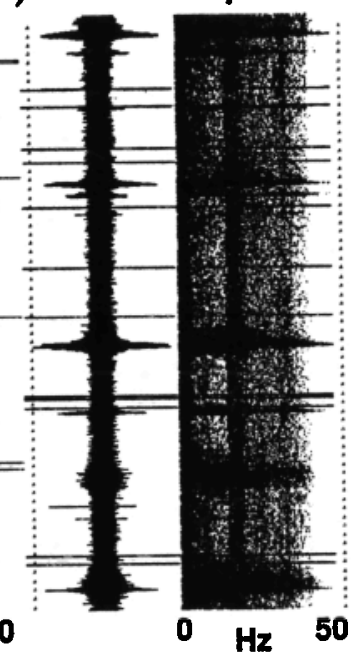

c) S.I. Tremor

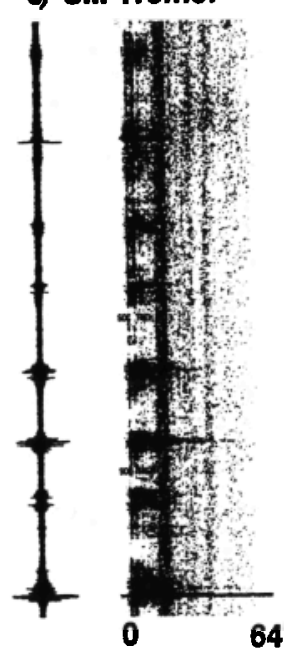

Figure 2. The time series and sonograms (frequency spectra) of (a) a beam that recorded the East Blanco Depression tremor-like events (January 7, 1994), (b) a beam that recorded EBD earthquakes (January 10, 1994), and (c) an omni-directional hydrophone record of volcanic tremors detected from the Socorro Island eruption (January 30, 1993). The vertical axis is time, increasing upward, with ticks representing 1-minute intervals; total time shown is 66 minutes. The horizontal axis shows both amplitude ( 2.5 volts for beams and 5 volts for the hydrophone) and spectra range ( $0-50 \mathrm{~Hz}$ for beams, $0-64 \mathrm{~Hz}$ for hydrophones). Sonograms were estimated using successive 1-second time series windows. Both the tremor from Socorro and the proposed tremor from the EBD are emergent, lowfrequency $(<25 \mathrm{~Hz})$, and have highly periodic arrival times. The EBD earthquakes tend to be impulsive, broad-band, and random in occurrence. Continuous energy in the 15-20 Hz band on all three records are Fin whale vocalizations. The ubiquitous broad-band clipped amplitude signals present in the beam records are electronic system noise. 
Pacific basin [Talandier and Okal, 1995]. Ten days later, the crew of the sailing vessel Mystique observed a steam column and a $6000 \mathrm{~m}^{2}$ mat of scoriaceous-lava blocks floating in -140 $\mathrm{m}$ of water about $3 \mathrm{~km}$ offshore of Socorro Island [BGVN, 1993]. In April 1993, the Mexican Navy performed a bathymetric survey in the area and imaged a new (328 $\mathrm{m}$ deep) conical vent extending westward from the island [Ignacio Galindo, Universidad de Colima, personal communication]. The Socorro Island T-wave signals were detected by the SOSUS hydrophone arrays almost continuously throughout the following year. The Socorro T-wave tremor events were similar to the tremor-like East Blanco events in having long duration, low frequency, and very periodic arrival times. During the peak tremor activity from Socorro, T-wave signals arrived roughly every 10 to 20 minutes.

Figure 3 shows a histogram of the T-wave earthquake and tremor time-frequency distribution. The tremor-like events initiated the activity at the EBD with 11 events on January 2. After a 2-day quiet period, tremors began again on January 5 and occurred discontinuously during the next 11 days. Peak tremor activity was observed on January 12 (64 events) and January 30 ( 57 events), with a period of near-quiescence from January 16 through 26 . The earthquakes began on January 9 , and intense earthquake activity lasted through January 12 , with earthquakes occurring sporadically thereafter. A total of $\sim 69$ earthquakes and $\sim 400$ tremor events were detected during the entire month of seismo-acoustic activity, with earthquake and tremor activity peaking on different days. By comparison, the ridge-crest eruption observed at the CoAxial Segment generated very few tremors but nearly $700 \mathrm{~T}$-wave earthquakes during the 3 weeks of peak activity [Dziak et al., 1995]. Rise times of both earthquakes and tremor T-wave events from the EBD were analyzed for indications that the source of the events shoaled over time. Neither showed clear evidence of a change in source depth during the intrusion episode.

\section{Response Efforts}

Since the EBD T-wave activity was interpreted as potentially volcanogenic, ground-truthing water-column and seafloor surveys were initiated. The NOAA ship Discoverer arrived on site on January 27, and six CTD/rosette casts were taken around (four directly over) the EBD during the next few days. Two of the casts showed excesses in ${ }^{3} \mathrm{He}$ and temperature compared to background values. The highest water-column signals were detected at Cast 6 , directly above the central bathymetric high within the basin (Figure 1). The ${ }^{3} \mathrm{He}$ profile for Cast 6 reached

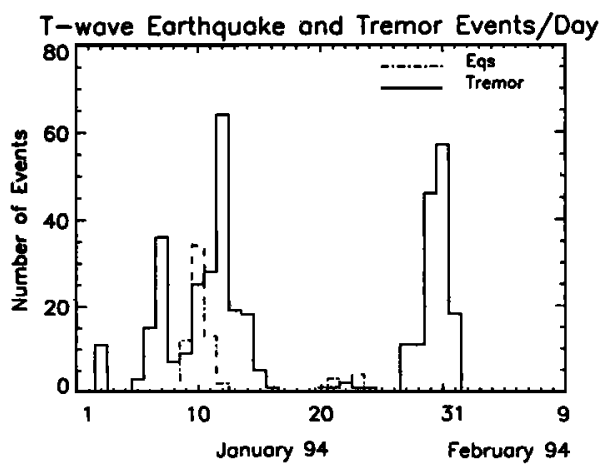

Figure 3. Histogram showing time and frequency distribution of the East Blanco Depression T-wave earthquake and tremor-like events. A brief period of tremor activity began on January 2, which was followed by nearly continuous tremor activity from January 5 through January 16. Peak tremor activity occurred on January 12 (64 events) and 30 (57 events), with a 5-day quiescent period separating the two main clusters of events. Earthquakes began on January 9 and lasted through January 12, with earthquakes occurring sporadically thereafter. A total of 69 earthquakes and 400 tremor events were detected during the month of seismoacoustic activity.

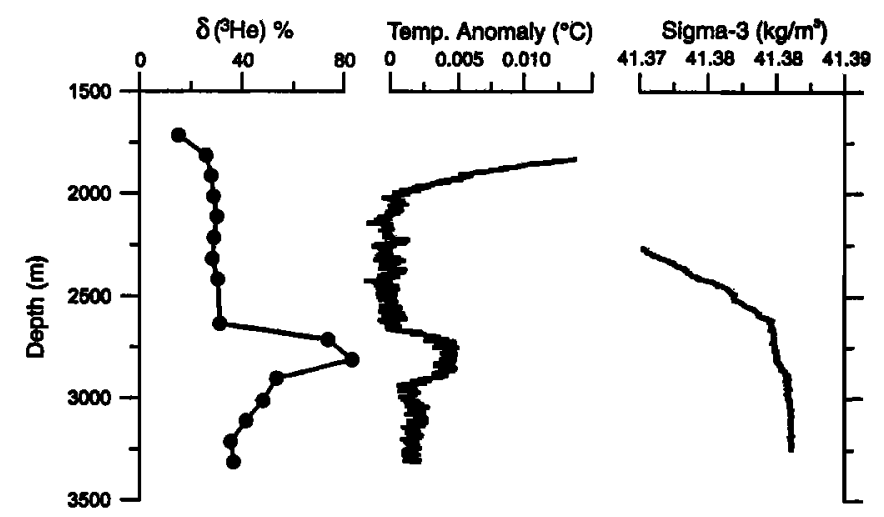

Figure 4. Profiles of ${ }^{3} \mathrm{He} /{ }^{4} \mathrm{He}$ ratio, temperature anomaly $\Delta \mathrm{T}$, and potential density $\sigma_{3}$ versus depth for Cast 6 . The largest ${ }^{3} \mathrm{He}$ anomaly occurs at $\sim 2800 \mathrm{~m}$ depth, which corresponds to the sill depth of the basin and is also the depth below which there is a marked decrease in the density gradient. The ${ }^{3} \mathrm{He}^{4} \mathrm{He}$ ratio is expressed as $\delta\left({ }^{3} \mathrm{He}\right) \%$, which is defined as $\delta\left({ }^{3} \mathrm{He}\right)=100 *\left(\mathrm{R}_{\text {sarnple }}\right.$ J $R_{\text {air }}-1$, where $R_{\text {sample }}=3 \mathrm{He} / 4 \mathrm{He}$, and $R_{\text {air }}=1.39 \times 10^{-6}$ is the ${ }^{3} \mathrm{He} /{ }^{4} \mathrm{He}$ ratio in air. The temperature anomaly $\Delta \mathrm{T}$ is calculated as the deviation of potential temperature from the background potential temperature vs. potential density relationship in the region. $\mathrm{O}_{3}$ is density corrected for adiabatic effects and referenced to 3000 decibars pressure.

a maximum value of $\delta\left({ }^{3} \mathrm{He}\right)=83 \%$ at a depth of $2800 \mathrm{~m}$, $\sim 800 \mathrm{~m}$ above the basin floor (Figure 4 ). This large excess in ${ }^{3} \mathrm{He}$, comparable to values observed directly over active blacksmoker vent fields, was accompanied by a small $\left(\sim 0.005^{\circ} \mathrm{C}\right)$ temperature anomaly $(\Delta \mathrm{T})$ at the same depth (Figure 4). The corresponding ${ }^{3} \mathrm{He} / \mathrm{Heat}$ ratio for the anomalous fluid residing at $2800 \mathrm{~m}^{\text {depth was } 8.7 \times 10^{-12} \mathrm{cc} \mathrm{STP} \mathrm{cal}}{ }^{-1}$, higher than any other hydrothermal ${ }^{3} \mathrm{He} /$ heat ratios observed on the Juan de Fuca-Gorda Ridge system [Lupton et al., 1995]. The large rise height of the hydrothermal fluid ( $800 \mathrm{~m}$ above the bottom) might be interpreted as evidence for a single catastrophic release of hydrothermal fluid resulting from magma injection into the shallow crust of the EBD. However, the hydrothermal layer detected in Cast 6 does not have the thickness or high-temperature anomaly associated with event plumes observed previously on the Juan de Fuca Ridge [Baker et al., 1995]. Furthermore, the apparent large rise height of the hydrothermal plume in the EBD can be attributed to the low density gradient in the water column below the basin sill depth, which allows plumes to ascend more easily (Figure 4). Thus the water-column anomalies in ${ }^{3} \mathrm{He}$ and temperature detected in January, 1994 are probably due to a long-term accumulation of hydrothermal input rather than a single catastrophic release of fluid directly associated with the T-wave events.

On June 18 and 19, 1994, the R/V Atlantis II deployed the USGS camera system in two parallel tows from southeast to northiwest across the basin (Figure 1). Both camera tows crossed the central-bathymetric high within the basin. Photographs and video from the tows showed the shallow area to be a constructional pillow-lava mound of a few square kilometers in area. None of the pillow lavas surveyed appeared to be recently erupted and are at least decades old. Additional bottom photographs along the northwest base of the volcanic edifice showed hydrothermal crusts and sediments that probably formed by lowtemperature hydrothermal discharge.

A SeaBeam resurvey of the basin area was done in late August, 1994 by the Discoverer to look for any depth changes that might be associated with a volcanic eruption. The results of the survey were equivocal due to the low quality of the navigation in the original survey and the difficulty of resolving depth changes on steep slopes, which are common in this area.

The last response effort to date occurred September 4-6, 1994, when a traverse was conducted across the floor of the EBD using the U.S. Navy's Advanced Tethered Vehicle (ATV). 
The ATV dive lasted 36 hours, during which the constructional pillow-lava mound and the basin's western boundary scarp were surveyed (Figure 1). Small blocks and mounds of volcanic breccia cemented by barite, silica, and sulfide minerals were found in the vicinity of the target vent area (northwest base of the pillow-lava mound). The region between the volcanic mound and the western edge of the basin was almost exclusively constructional pillow-lava terrain. Along the western edge of the basin several small cones (hornitos), formed within the pillowlava, were observed. Surveys up the western basin (east-facing) scarp showed it to be heavily sedimented. Finally, an area of active hydrothermal mounds was found near the vent position indicated by the camera tow data, about $1.5 \mathrm{~km}$ north of Cast 6 where the ${ }^{3} \mathrm{He}$ anomaly was detected (Figure 1). The mounds ( $\sim 5 \mathrm{~m}$ high and $\sim 15 \mathrm{~m}$ in diameter) are composed of unconsolidated $\mathrm{Fe}$ oxide deposits and bacterial mats. Although no shimmering water was observed, temperature probe measurements up to $60^{\circ} \mathrm{C}$ were recorded within $30 \mathrm{~cm}$ of the mound surface. To our knowledge, this is the first known active hydrothermal site discovered within an oceanic transform fault system, albeit in an extensional regime along the transform.

\section{Summary}

The great depth of the East Blanco Depression (3650 m) suggests that it is an area of crustal thinning as well as low magma supply. Although surface eruptions at this site might be rare, low-temperature, diffuse hydrothermal vent sites might be characteristic because of high heat flow.

The major results of this study can be summarized as follows:

(1) The January 1994 East Blanco Depression T-wave swarm included earthquakes and tremor-like events and is interpreted as volcanogenic.

(2) Although there is no evidence of extrusion with this Twave swarm, the EBD has been the site of volcanism in the recent geologic past (100 yrs?). Volcanic activity in a pullapart basin like the EBD probably occurs in a less organized, more diffuse zone than on a primary seafloor spreading center.

(3) An active hydrothermal center was found near the base of the major constructional pillow-lava edifice within the basin. Active hydrothermal mounds appear to consist of low-temperature precipitate and bacterial mats. The entire mound area is probably warm, with temperature measurements up to $60^{\circ} \mathrm{C} \sim 30 \mathrm{~cm}$ inside individual mound surfaces. This is the first discovery of an active hydrothermal vent site along an oceanic fracture zone.

(4) The ${ }^{3} \mathrm{He}$ and temperature anomalies observed at the $2800-\mathrm{m}$ sill depth most likely resulted from a gradual accumulation of hydrothermal fluids within a density horizon over time, rather than from a sudden catastrophic release of fluid directly associated with the T-wave swarm.

(5) The previous observations, in conjunction with the lack of a clear bathymetric change within the basin, suggests that either the eruptive site has not yet been located or the Twave tremor signals and earthquakes were generated by magma movement at depth.

Acknowledgments. The authors wish to thank A. Schreiner for evaluation of the earthquake and tremor event rise times, L. Evans for collecting and processing the helium samples, $\mathrm{K}$. McTaggart for collecting and processing CTD data, J. Getsiv for enthusiastic graphics production, V. Smith and S. Ross for excellent at-sea support, and $\mathrm{H}$. Chezar for providing excellent support for the USGS camera system onboard the Atlantis II. Also, the authors owe a great debt of gratitude to the officers and crew of the ships Laney Chouest, Discoverer, Atlantis II, and the Deep Submergence Unit/Advanced Tethered Vehicle for expertise at sea without which this study could not have been conducted. Support for this work was provided by NOAA's VENTS Program, and the NOAA Undersea Research Program 1994 Laney Chouest Cruise Series. PMEL contribution 1688.

\section{References}

Baker, E. T., G. J. Massoth, R. A. Feely, R. W. Embley, R. E. Thomson, and B. J. Burd, Hydrothermal event plumes from the CoAxial seafloor eruption site, Juan de Fuca Ridge, Geophys. Res. Lett., 22, 147-150, 1995.

Bulletin of the Global Volcanism Network, 18, No. 1, 9-12, January 31, 1993.

Einarsson, P., Earthquakes and present-day tectonism in Iceland. Tectonophys., 189, 261-279, 1991.

Dziak, R. P., C. G. Fox, and R. W. Embley, Relationship between the seismicity and geologic structure of the Blanco Transform Fault Zone, Mar. Geophys. Res., 13, 203-208, 1991.

Dziak, R. P, C. G. Fox, and A. E. Schreiner, The June-July 1993 Seismo-acoustic event at CoAxial Segment, Juan de Fuca Ridge: Evidence for a lateral dike injection, Geophys. Res. Lett., 22, 135-138, 1995 ,

Embley, R. W., and D. S. Wilson, Morphology of the Blanco Transform Fault Zone-NE Pacific: Implications for its tectonic evolution, Mar. Geophys. Res., 14, 25-45, 1992.

Embley, R. W., W. W. Chadwick, I. R. Jonasson, D. A. Butterfield, and E. T. Baker, Initial results of the rapid response to the 1993 CoAxial event: Relationships between hydrothermal and volcanic processes, Geophys. Res. Lett., 22, 143-146, 1995.

Fox, C. G., R. P. Dziak, H. Matsumoto, and A. E. Schreiner, Potential for monitoring low-level seismicity on the Juan de Fuca Ridge using fixed hydrophone arrays, Mar. Tech. Soc., 27(4), 22-30, 1994.

Fox, C. G., W. E. Radford, R. P. Dziak, T-K Lau, H. Matsumoto, and A. E. Schreiner, Acoustic detection of a seafloor spreading episode on the Juan de Fuca Ridge using military hydrophone arrays, Geophys. Res. Lett., 22, 131-134, 1995.

Hekinian, R., D. Bideau, M. Cannat, J. Francheteau, and R. Hebert, Volcanic activity and crust-mantle exposure in the ultrafast Garret Transform Fault near $13^{\circ} 28^{\prime} \mathrm{S}$ in the Pacific, Earth Planet. Sci. Lett., 108, 259-275, 1992.

Kastens, K. A., W. B. F. Ryan, and P. J. Fox, Structural and volcanic expression of a fast slipping ridge-transform-ridgeplate boundary: Sea Marc I and photographic surveys at the Clipperton Transform Fault, J. Geophys. Res., 91, 3469-3488, 1986.

Lupton, J. E., E. T. Baker, G. J. Massoth, R. E. Thomson, B. J. Burd, D. A. Butterfield, R. W. Embley, and G. A. Cannon, Variations in water column ${ }^{3} \mathrm{He} /$ heat ratios associated with the 1993 CoAxial event, Juan de Fuca Ridge, Geophys. Res. Lett., 22, 155-158, 1995.

Newmark, R. L., P. W. Kasameyer, and L. W. Younker, Shallow drilling in the Salton Sea region: The thermal anomaly, $J$. Geophys. Res., 93, 13,005-13,023, 1988.

National Earthquake Information Center, Preliminary Determination of Epicenters, United States Geological Survey, January, 1994.

Perfit, M. R., D. J. Fornari, J .F. Casey, K. A. Kastens, W. I. Ridley, P. D. Kirk, M. Edwards, D. Desonie, J. R. Reynolds, R. Shuster, S. Paradis, C. Xia, and D. Barlaz, Recent volcanism in the Siqueiros Transform Fault: Eruption of picritic and high$\mathrm{MgO}$ basalts and implications for MORB magma genesis, Earth Planet. Sci. Lett., in press, 1993.

Talandier, J., and E. A. Okal, Monochromatic T-waves from underwater volcanoes in the Pacific Ocean: Ringing witnesses to degassing processes? Bull. Seism. Soc. Am., in press, 1995.

R. P. Dziak and W. W. Chadwick, Cooperative Institute for Marine Resources Studies, Dept. of Geosciences (R.P.D.), Oregon State University, Hatfield Marine Science Center, Newport, OR 97365.(e-mail:dziak@pmel.noaa.gov,chadwick@pmel.noaa.gov)

C. G. Fox, R. W. Embley, and J. E. Lupton, National Oceanic and Atmospheric Administration, Pacific Marine Environmental Laboratory, Hatfield Marine Science Center, Newport, OR 97365. (e-mail: fox@pmel.noaa.gov, embley@pmel.noaa.gov, lupton@ pmel.noaa.gov)

G. C. Johnson, National Oceanic and Atmospheric Administration, Pacific Marine Environmental Laboratory, 7600 Sand Point Way NE, Seattle, WA 98115 . (e-mail: gjohnson@pmel.noaa.gov)

R. A. Koski, United States Geological Survey, 345 Middlefield Rd., Menlo Park, CA 94025. (e-mail: randy@octopus.wr.usgs.gov)

(Received September 13, 1995; accepted October 7, 1995.) 